\title{
Effects of Wheat Cultivar Mixtures on Epidemic Progression of Septoria Tritici Blotch and Pathogenicity of Mycosphaerella graminicola
}

\author{
Christina Cowger and Christopher C. Mundt
}

Department of Botany and Plant Pathology, Oregon State University, Cordley Hall 2082, Corvallis 97331. Accepted for publication 18 February 2002.

\section{ABSTRACT}

Cowger, C., and Mundt, C. C. 2002. Effects of wheat cultivar mixtures on epidemic progression of Septoria tritici blotch and pathogenicity of Mycosphaerella graminicola. Phytopathology 92:617-623.

\begin{abstract}
The effects of host genotype mixtures on disease progression and pathogen evolution are not well understood in pathosystems that vary quantitatively for resistance and pathogenicity. We used four mixtures of moderately resistant and susceptible winter wheat cultivars naturally inoculated with Mycosphaerella graminicola to investigate impacts on disease progression in the field, and effects on pathogenicity as assayed by testing isolate populations sampled from the field on greenhousegrown seedlings. Over 3 years, there was a correspondence between the mixtures' disease response and the pathogenicity of isolates sampled from them. In 1998, with a severe epidemic, mixtures were $9.4 \%$ less diseased than were their component pure stands $(P=0.0045)$, and pathogen populations from mixtures caused $27 \%$ less disease $(P=0.085)$ in greenhouse assays than did populations from component pure stands.
\end{abstract}

In 1999, the epidemic was mild, mixtures did not reduce disease severity $(P=0.39)$, and pathogen populations from mixtures and pure stands did not differ in pathogenicity $(P=0.42)$. In 2000 , epidemic intensity was intermediate, mixture plots were $15.2 \%$ more diseased than the mean of component pure stands $(P=0.053)$, and populations from two of four mixtures were 152 and $156 \%$ more pathogenic than the mean of populations from component pure stands $(P=0.043$ and 0.059 , respectively). Mixture yields were on average 2.4 and $6.2 \%$ higher than mean component pure-stand yields in 1999 and 2000, respectively, but the differences were not statistically significant. The ability of mixtures challenged with $M$. graminicola to suppress disease appears to be inconsistent. In this system, host genotype mixtures evidently do not consistently confer either fitness benefits or liabilities on pathogen populations.

Additional keywords: host genetic diversity, partial resistance, quantitative pathosystems, Triticum aestivum.
Although there is extensive literature about the use of multiline cultivars and cultivar mixtures to manage disease $(6,13,36)$, the vast majority concerns pathosystems in which pathogenicity (Vanderplank, 35) and resistance vary qualitatively. In particular, the study of pathogen evolution within mixtures has been almost exclusively confined to such pathosystems. Little is known about the selective effects of cultivar mixtures on pathogen evolution in disease systems where resistance is partial.

Mathematical modeling by Jeger et al. (14) indicated that cultivar mixtures may either decrease, increase, or have no effect on the severity of disease caused by nonspecialized pathogens. In the case of Mycosphaerella graminicola, causal agent of the foliar disease Septoria tritici blotch in wheat (Triticum aestivum), one might expect mixtures to be relatively ineffective at disease suppression for two reasons. First, there is considerable evidence that mixtures are less effective against splash-dispersed pathogens than against pathogens whose secondary propagules are windborne (13). This is likely due largely to the steeper dispersal gradient of splash-dispersed propagules, more of which fall upon the hosts of origin (28), thus obviating the dilution advantage (16) of mixing host genotypes. Second, mixtures are predicted to be less effective in suppressing disease when initial inoculum is abundant and well distributed (28). Indeed, Abbott et al. (1) found little benefit from mixing barley cultivars to manage Rhynchosporium secalis, a splash-dispersed pathogen with numerous initial infection foci at their experimental site.

Corresponding author: C. Cowger; E-mail address: cowgerc@bcc.orst.edu

Publication no. P-2002-0416-02R

(C) 2002 The American Phytopathological Society
Data so far indicate some promise for controlling Septoria diseases with mixtures, but most experiments have involved more than one pathogen. Mundt et al. (26) reported that in plots inoculated with Pseudocercosporella herpotrichoides, winter wheat mixtures reduced Septoria tritici blotch severity by 27,9 , and $15 \%$ compared with mean severities of pure components over 3 years. However, the greatest reductions in disease severity were brought about by mixtures including highly resistant cv. Gene, which has since been shown to select for isolates specifically adapted to it (9). Mille and Jouan (25) found that winter wheat mixtures sustained an average of $8 \%$ less disease caused by $M$. graminicola, Phaeosphaeria nodorum, and Puccinia recondita and yielded an average of $7 \%$ better than the mean of component pure stands. Jeger et al. (15) found that spring and winter wheat mixtures lightly infected with Phaeosphaeria nodorum (anamorph Stagonospora nodorum) were significantly less diseased and yielded significantly better than the geometric mean of component pure stands. In an experiment involving several foliar pathogens, Manthey and Fehrmann (22) found that levels of Phaeosphaeria nodorum conidia on flag leaves of winter wheat cultivars in mixtures did not differ statistically from similar counts for component pure stands.

Much of the theoretical and empirical investigation of pathogen evolution in mixtures has concerned the potential for selecting complex races (those possessing multiple virulence genes), the relative fitness of complex and simple races, and the extent to which complex races, if favored, could erode the benefits of multiline cultivars and cultivar mixtures $(4,12,19,21,23,27,29,36)$. Although this discussion has focused on qualitatively varying pathosystems, it may be relevant to quantitative systems as well. Several researchers $(8,10,12,20)$ have suggested that differential 
adaptation to host genetic background could result in a higher reproductive rate for simple races compared with complex races. Differential adaptation could also operate in pathosystems not characterized by gene-for-gene interactions or specificity, and thus reduce epidemic progression in cultivar mixtures.

The $M$. graminicola-wheat system is useful for addressing these issues because resistance in most cultivars is partial. In addition, the pathogen population is highly genetically diverse (24) and thus there is strong potential for within-season adaptation. Further, Septoria tritici blotch is a growing worldwide economic threat to wheat production (11), and there has been insufficient investigation of the potential to manage this disease with cultivar mixtures.

We conducted an experiment in which naturally inoculated populations of $M$. graminicola were subjected to host selection in plots of pure stands and mixtures of winter wheat. The pathogenicity of isolates derived from pure stands was compared with that of isolates from mixtures by testing the isolates as bulked populations on seedlings in the greenhouse. We assessed disease severity and yield for field plots of mixtures and pure stands in order to help evaluate the utility of cultivar mixtures for managing Septoria diseases.

\section{MATERIALS AND METHODS}

Plot establishment and field disease assessment. Field plots of winter wheat were established during the 1997-98, 1998-99, and 1999-2000 growing seasons at the Oregon State University Botany and Plant Pathology Field Laboratory in Corvallis. Four treatments consisted of cvs. Cashup and Madsen, moderately resistant (MR) to Septoria tritici blotch, and cvs. Stephens and W-301, susceptible. In addition, the four possible 1:1 mixtures of MR and susceptible cultivars were planted. 'Stephens' and 'Madsen' were commonly grown in western Oregon where the experiment took place, whereas 'Cashup' and 'W-301' were not. Mean Julian days to heading, based on data from 1994 (17) and 1995 (18) for Corvallis, were Cashup, 145; Madsen, 140.5; Stephens, 138; and $\mathrm{W}-301,138.5$.

Treatments were assigned randomly to plots in each of four replicate blocks. In the first 2 years, each treatment occupied two adjacent planting units $(1.5 \times 6.1 \mathrm{~m})$ of six rows each $(20 \mathrm{~cm}$ between rows), whereas in the third year, treatments were applied only to single planting units in order to conserve space. Equalsized plots of wheat and barley were alternated in a checkerboard pattern so that the barley provided a buffer between the wheat plots. Plots were planted on 20 October 1997, 7 October 1998, and 12 October 1999 with a plot drill at a rate of 2,740 seeds per planting unit. Plots received a balanced starter fertilizer preplanting and $110 \mathrm{~kg} \mathrm{~N} / \mathrm{ha}$ at late tillering. Weed control was via appropriate herbicides, with hand weeding as necessary.

Visual assessments of percent diseased leaf area were conducted by two assessors for each plot on a whole-canopy basis, taking into account all leaf layers, eight times each year between early to middle February and early to middle June. Areas under the disease progress curve (AUDPC) were calculated for all plots using the midpoint method (7).

Leaf sampling and isolations. Leaves infected with $M$. graminicola were collected from the field plots on 12 June 1998, 24 June 1999, and 27 June 2000 near the end of each growing season, after there had been ample opportunity for host treatments to exert selective influences on the pathogen population. In 1998 and 1999, leaves were collected as follows: along a diagonal transect across each plot, the flag leaf (1998) or the leaf penultimate to the flag leaf (F-1) (1999) was collected from each of two adjacent plants chosen at random in each of the 10 innermost rows of the plot, the exterior rows being excluded to avoid edge effects. In 2000, when only four rows remained after excluding the outermost rows, F-1 leaves were sampled from each of two randomly chosen plants at 10 points along an S-shaped transect, such that there were two or three sampling points in each row. F-1 leaves were collected in 1999 and 2000 because flag leaves on the more resistant cultivars had too few lesions to assure that isolates could be obtained. Leaves were bagged separately by row.

In the laboratory, one monopycnidial isolate of $M$. graminicola was obtained for each sampling point in each replicate of each cultivar of origin each year, such that there were 10 isolates from each field plot or 40 isolates per treatment. Isolations were made by placing leaf segments bearing lesions in petri dishes lined with moistened filter paper overnight, and transferring cirrhi individually with a sterile needle to plates of yeast-malt agar amended with $50 \mathrm{mg} / \mathrm{liter}$ of streptomycin. The isolates were stored at $4{ }^{\circ} \mathrm{C}$ and transferred to fresh yeast-malt agar every 3 to 5 months.

Greenhouse trials. Pathogen populations derived from each field plot were evaluated in the greenhouse during the winter and spring following their collection in the field. Isolates collected in 1999 were tested twice (in 2000 and 2001) to assess repeatability of the methodology. In each year of greenhouse testing there were four replicates, conducted in pairs, with each replicate testing a pathogen population from a different block in the field experiment. Tester cultivars to which the populations were applied were the same as those planted in pure stands in the field.

The experimental unit was a pot of seedlings. In 1999, plants were raised in 10-cm plastic pots filled with a $1: 1: 1: 2$ mixture of peat/sand/loam/no. 8 pumice amended with Osmocote 18-6-12 extended time-release fertilizer (Scott-Sierra Horticultural Products Co., Marysville, $\mathrm{OH}$ ) at a rate of approximately $1 \mathrm{~g}$ per pot at seeding. Approximately 13 seeds of a cultivar were sown in each pot, and seedlings were thinned to 10 plants per pot at about 18 days after planting. The plants were grown under sodium halide lighting to extend the day length to $16 \mathrm{~h}$, and watered as needed. To control powdery mildew, plants were treated when necessary with $50 \mathrm{ml}$ of a soil drench of ethirimol ( $0.11 \mathrm{~g}$ a.i./liter), which has no influence on the development of $M$. graminicola. The greenhouse temperature was maintained at 20 to $25^{\circ} \mathrm{C}$.

During the second greenhouse season, because of problems in the previous year with emergence, growth, and nondisease-related necrosis, plants were raised in Black Gold all-organic potting soil

TABLE 1. Conduciveness of three study years to epidemics of Septoria tritici blotch (caused by Mycosphaerella graminicola) in winter wheat

\begin{tabular}{|c|c|c|c|c|c|c|c|c|c|c|c|}
\hline \multirow[b]{2}{*}{ Year } & \multicolumn{2}{|c|}{$\begin{array}{l}\text { Cumulative generations } \\
\text { (Dec.-Jun.) })^{\mathrm{a}}\end{array}$} & \multicolumn{7}{|c|}{ Number of $\geq 5$-mm rain-days ${ }^{b}$} & \multicolumn{2}{|c|}{ Rain-days $^{c}$} \\
\hline & MR & S & Dec. & Jan. & Feb. & Mar. & Apr. & May & Jun. & 1 Apr.-14 Jun. & 11 May-14 Jun. \\
\hline 1998 & 6.70 & 8.17 & 6 & 14 & 14 & 9 & 3 & 14 & 2 & 34 & 18 \\
\hline 1999 & 6.32 & 7.59 & 12 & 14 & 18 & 10 & 0 & 4 & 2 & 32 & 11 \\
\hline 2000 & 6.39 & 7.66 & 11 & 14 & 11 & 6 & 2 & 6 & 1 & 35 & 15 \\
\hline
\end{tabular}

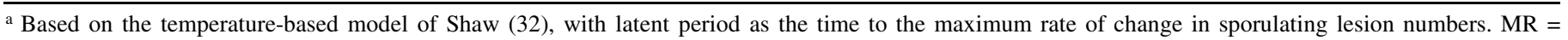
moderately resistant; $\mathrm{S}=$ susceptible.

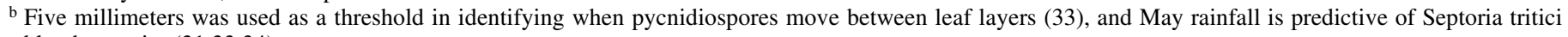
blotch severity $(31,33,34)$.

c Based on Shaner and Finney (31), counts are of days with any amount of rain. 
(Black Gold, Inc., Hubbard, OR) amended with approximately $2.5 \mathrm{~g}$ of Osmocote per pot. Pots were also fertilized weekly with $50 \mathrm{ml}$ of Peters water-soluble 20-20-20 fertilizer (United Industries Corp., St. Louis) at a rate of 3.8 g per liter of water. Watering, temperature, and lighting were the same as in 1999. Practices in the third greenhouse season were the same as in the second.

Inoculum preparation and inoculation. Isolates of M. graminicola were increased individually for 4 days on fresh yeast-malt agar. Spores of each isolate were mixed by field plot in an equiproportional suspension and adjusted to $10^{5}$ spores per $\mathrm{ml}$ for 1998 and $10^{6}$ spores per $\mathrm{ml}$ for 1999 and 2000. The increased concentration was selected as optimal in the course of testing soil mix, fertilizers, and inoculum concentration.

When plants were 21 days old (two to three fully expanded leaves), each spore population was applied to a group of four pots, one pot of each tester cultivar, by means of a spray bottle and turntable. For the 1998 isolates and the first trial of the 1999 isolates, $25 \mathrm{ml}$ was used, whereas $50 \mathrm{ml}$ was used for the second trial of the 1999 isolates and the 2000 isolates. After inoculation, the plants were kept in a greenhouse mist chamber for $96 \mathrm{~h}$. Noninoculated control plants were sprayed with water and surfactant only, but otherwise treated in the same manner as inoculated plants, in order to control for contamination among pots.

Greenhouse disease assessment. In order to assess disease levels of all plants in a given experiment in the same day, two workers conducted the assessments, each assessing half of the plants in each pot. The percentage of the second leaf from the base of the plant covered by Septoria tritici blotch lesions and lesionassociated necrotic area was estimated visually for each plant in each pot at 21 days after inoculation.

Data analysis. Within a given year, AUDPC, yield, and greenhouse disease severity data were analyzed using the SAS procedure PROC MIXED (SAS Institute, Cary, NC). Means were separated and differences estimated using linear contrasts. The 2000 AUDPC and greenhouse data were $\log _{\mathrm{e}}$-transformed to improve homogeneity of variances. Results of the two greenhouse trials of 1999 isolates were similar, with nonsignificant by-trial interactions, and thus were combined for statistical analysis.

A correlation analysis was performed across years to test the association between (i) the effect of mixtures on disease severity in the field and (ii) the effect of mixtures on pathogenicity of isolate populations. The first variable was measured as the percent difference between mixture AUDPCs and the mean of component pure-stand AUDPCs. The second variable was measured in the greenhouse as the percent difference between (i) the mean disease severity caused by a mixture population tested separately on the two cultivars of origin (e.g., the mean of the Cashup/Stephens population tested on Cashup and the mean of the same population tested on Stephens) and (ii) the mean disease severity caused by the two component pure-stand populations tested separately on their respective cultivars of origin (in this case, the mean of the Cashup population tested on Cashup and the Stephens population tested on Stephens).
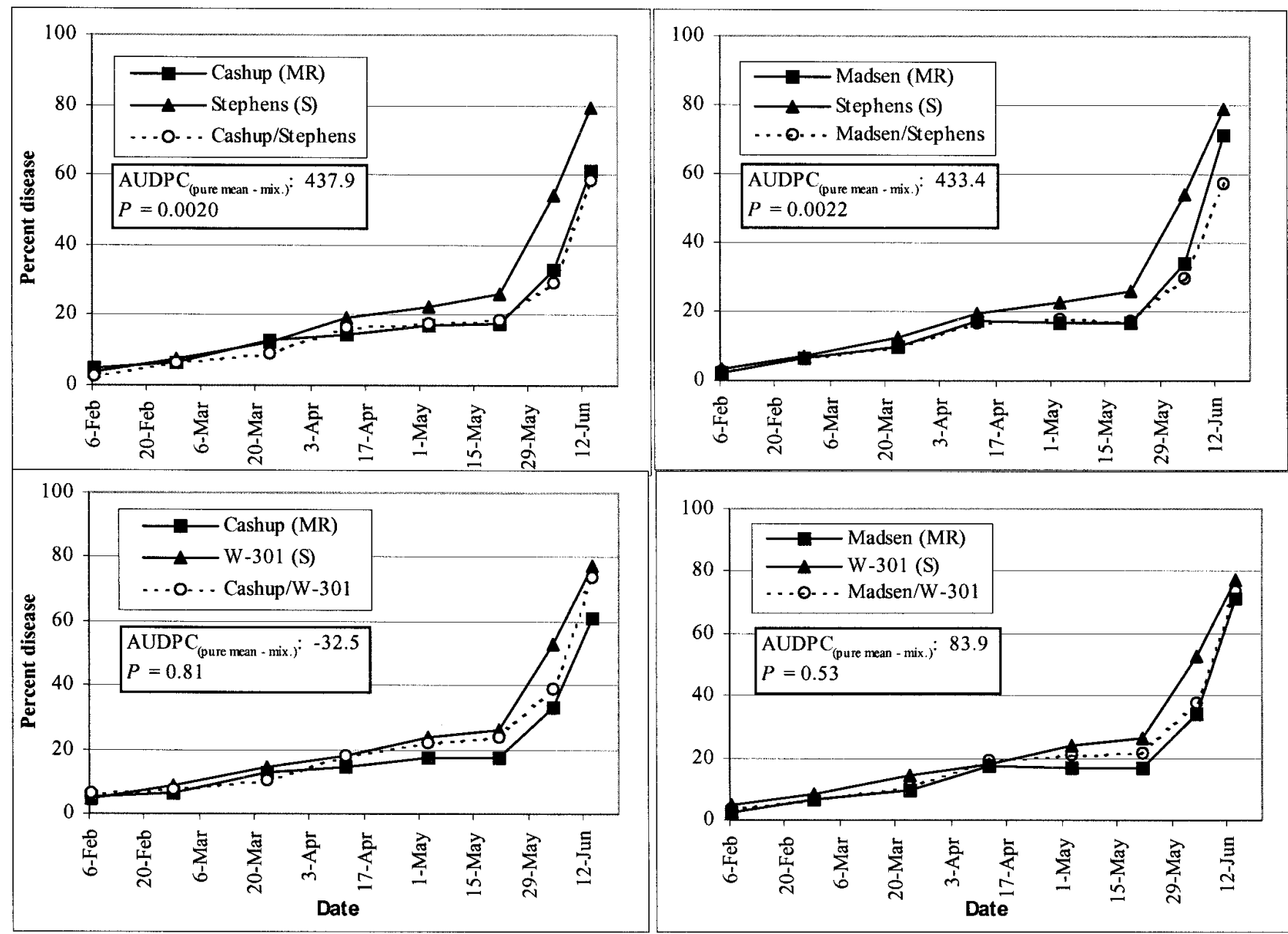

Fig. 1. Disease progress curves for four 1:1 moderately resistant (MR)-susceptible (S) mixtures of winter wheat naturally inoculated with Mycosphaerella graminicola in 1998. The mean area under the disease progress curve (AUDPC) for mixtures was $9.4 \%$ lower than the mean AUDPC for component pure stands (linear contrast, $P=0.0045$ ). Data are means of four field replicates. 


\section{RESULTS}

The three study years varied in conduciveness to Septoria tritici blotch according to measures developed by other researchers (Table 1). In 1998, both temperature and rainfall favored a severe epidemic. In 1999 and 2000, temperature was somewhat less conducive than in 1998. In 1999, a wet early spring was followed by a dry late spring, keeping ultimate disease severities relatively low, whereas in 2000 those conditions were reversed and, after a dry early season, disease developed strong later.

As might be expected, disease progress varied considerably among the three study years (Figs. 1 to 3 ). It should be noted that the flat portions of the disease progress curves in early season do not reflect an absence of disease increase; rather, pathogen reproduction approximately kept pace with vegetative growth during those periods. Overall, Septoria tritici blotch severity was greatest in 1998, followed closely by 2000 and then 1999 .

Performance of mixtures in suppressing disease varied among mixtures and among years (Figs. 1 to 3). In 1998, AUDPCs of mixtures were on average $9.4 \%$ lower than the mean of their component pure stands $(P=0.0045)$, whereas in 1999, AUDPCs of mixtures did not differ significantly from AUDPCs of component pure stands $(P=0.389)$. In 2000 , MR cultivars in pure stands sustained very low rates of disease despite the later intensification of disease on susceptible cultivars (Fig. 3), and mixtures were on average $15.2 \%$ more diseased than the mean of their component pure stands $(P=0.053)$.
Yields were not recorded for 1998 due to poor stand density in many plots. Yields of mixture plots exceeded the means of their component pure stands by an average of 2.4 and $6.2 \%$ in 1999 and 2000 , respectively, but no individual contrast or main-effect contrast of mixtures and pure stands was statistically significant at $P \leq 0.13$ (data not shown).

The mean disease severity caused by an isolate population sampled from a mixture and tested on its two component cultivars was compared with the mean disease severity caused by the relevant two pure-stand isolate populations on their respective cultivars of origin; e.g., the mean of 'Cashup'/'Stephens' isolate populations tested on 'Cashup' and on 'Stephens' versus the mean of 'Cashup' populations tested on 'Cashup' and 'Stephens' populations tested on 'Stephens' (Table 2). In 1998, populations sampled from mixtures in each case caused less disease than the mean of their counterpart pure-stand populations, and mixture populations were on average less pathogenic than component pure-stand populations $(P=0.085)$. In 1999 , mixture populations caused approximately the same amount of disease as the mean of their respective pure-stand populations. In 2000, populations from 'Cashup'/'Stephens' and 'Madsen'/'Stephens' caused greater disease severity than their pure-stand counterparts $(P=$ 0.043 and 0.059 , respectively). The mean severity caused by mixture populations was not significantly different from that caused by component pure-stand populations in 1999 and 2000 $(P=0.42$ and 0.29 , respectively). The higher levels of disease caused by the 1999 and 2000 populations relative to the
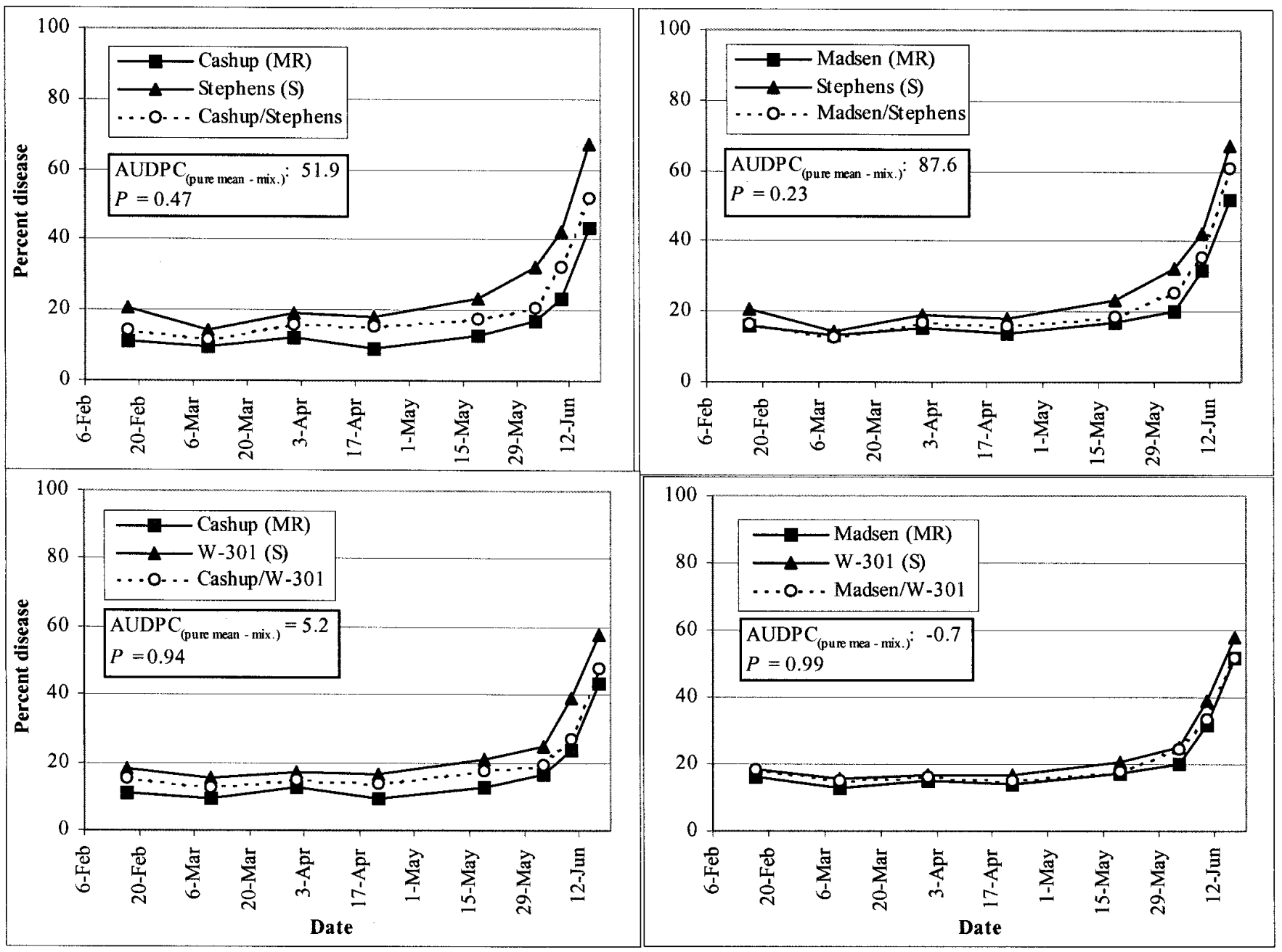

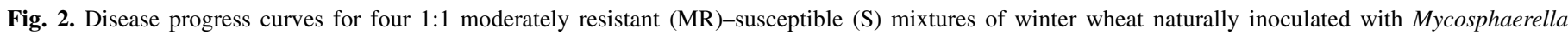

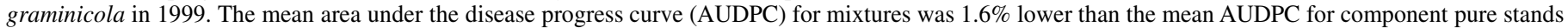
(linear contrast, $P=0.39$ ). Data are means of four field replicates. 
1998 populations were likely due to the changes in greenhouse cultural practices.

Mixture effects on disease in the field were weakly correlated with their effects on pathogenicity of populations derived from them (Pearson correlation coefficient $=0.46 ; P=0.13)$ (Fig. 4). A larger reduction in disease severity in mixture field plots was associated with a larger reduction in pathogenicity of populations derived from those plots.

In a further analysis, the performance of isolates from a given mixture on their cultivars of origin was compared with their performance on the other two testers (data not shown). Taken across mixtures, there was no evidence in any of the 3 years (linear contrasts; $P=0.75,0.86$, and 0.62 , respectively) of a tendency for mixture isolates to cause either more or less disease on their cultivars of origin. Similarly, there was no evidence that pure-stand isolates were more pathogenic to their cultivars of origin than to the other tester cultivars in any of the 3 years (data not shown) (linear contrasts; $P=0.76,0.99$, and 0.30 , respectively).

Isolates from the mixture of 'Madsen' and 'Stephens', the two cultivars that together accounted for $>75 \%$ of the wheat area in the Willamette Valley during the period 1995 to 2000, displayed inconsistency among the study years. In 1998, the 'Madsen'/ 'Stephens' population was least pathogenic relative to its purestand counterparts, whereas in 1999 and 2000, the pathogenicity of the 'Madsen'/'Stephens' populations exceeded the mean of their pure-stand counterparts to the greatest extent (Table 2).

\section{DISCUSSION}

Mixture effects on epidemics. Cultivar mixtures influenced Septoria tritici blotch severity differently in each of our three study years. In 1998, disease progress curves of three out of four mixtures closely resembled those of the MR component throughout the season, whereas in 2000 , three out of four mixture progress curves closely resembled those of the susceptible component. In 1999, disease progress curves for mixtures were intermediate between the MR and susceptible components. According to Wolfe (36), "with non-specialized pathogens that infect mixtures, we can say generally that, if disease spread in the susceptible component is hindered more than spread in the resistant component is increased, then the overall infection tends to that of the resistant component grown alone." Our results suggest that, in this pathosystem, environmental conditions may be an important determinant of whether infection levels in a given mixture tend more toward those of the resistant or the susceptible component.

A possible confounding factor is that our plot stands were generally sparser in 1998 than in the other 2 years; perhaps the denser stands in 2000 mixture plots overcame the disease-suppressing mechanism of decreased spatial density of susceptible plants (36). However, Jeger et al. (15) found no relationship between stand density and severity of Phaeosphaeria nodorum in mixed and pure-stand plots. In any case, one would expect that increased stand density would merely neutralize the diseasesuppressing benefit of mixtures, instead of increasing disease in
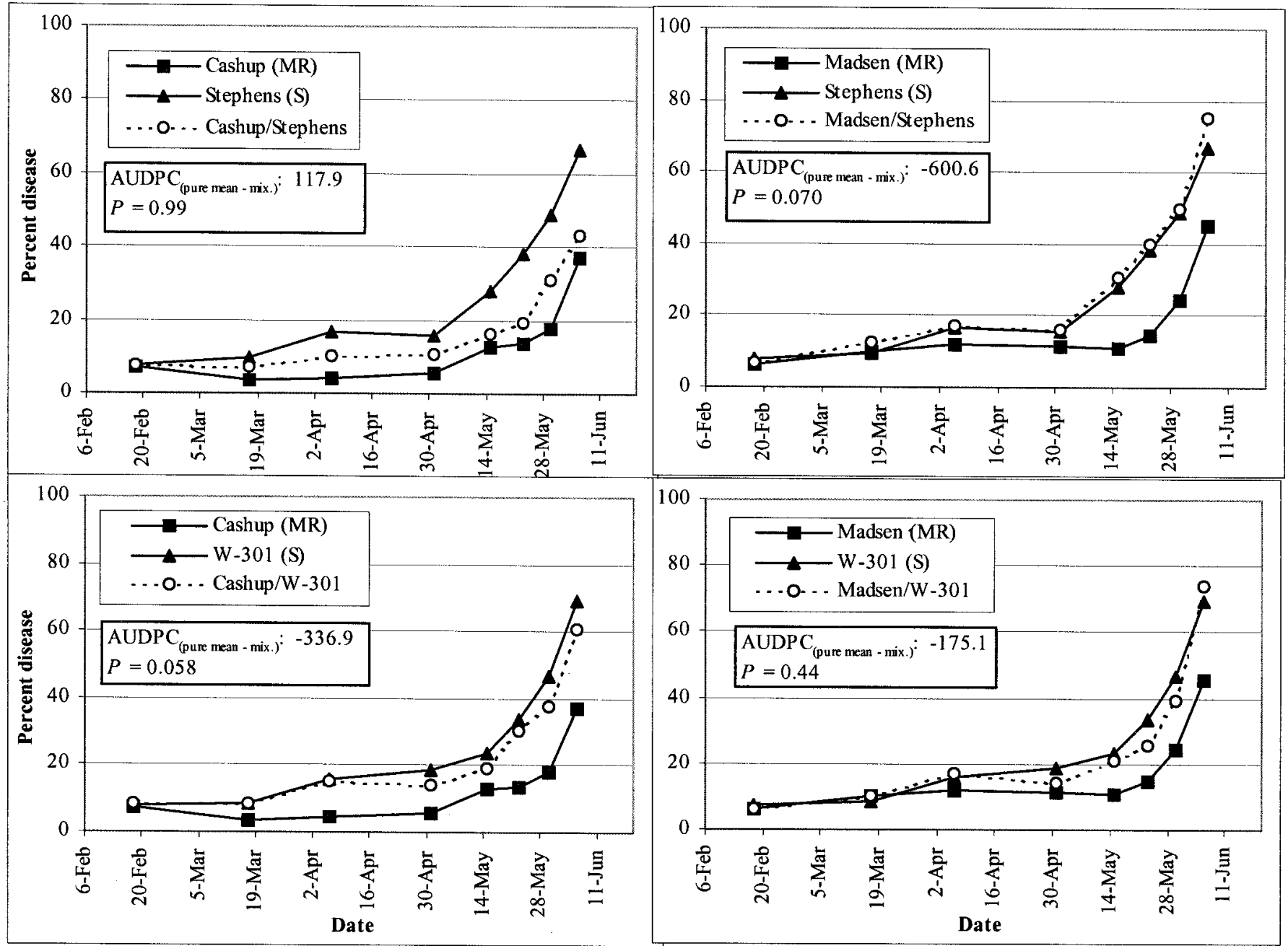

Fig. 3. Disease progress curves for four 1:1 moderately resistant (MR)-susceptible (S) mixtures of winter wheat naturally inoculated with Mycosphaerella graminicola in 2000. The mean area under the disease progress curve (AUDPC) for mixtures was $15.2 \%$ higher than the mean AUDPC for component pure stands (linear contrast, $P=0.053$ ). Data are means of four field replicates. 
mixture plots relative to component pure stands, as was actually observed.

Jeger et al. (14) hypothesized that, against nonspecific pathogens, cultivar mixtures may either decrease, increase, or have no effect on epidemic progression, depending on relative levels of sporulation and infection frequency of the mixture components. This does not seem a likely explanation for our results, however, because the variation in epidemiological effects that we observed was much greater among years than within years among mixtures. Large interactions of resistance components with environment would be required to alter the effects of host diversity on disease progression qualitatively from year to year.

Mixture effects on pathogenicity. Our goal in measuring pathogenicity in the greenhouse was to investigate whether disruptive selection reduced fitness of the pathogen population in mixtures, as was shown by Chin and Wolfe (8) for barley powdery mildew. Selection is disruptive at the population level if it operates on a given trait in different directions at different sites (5) or, in this case, in interactions with different host phenotypes. In a mixture, such disruptive selection requires adaptation to the genetic background of individual host cultivars. Though quantitative adaptation of $M$. graminicola to host genetic background has been demonstrated (2,3), we detected no such adaptation in our study. This was true even in 1998, when there was some evidence for reduced fitness of pathogen populations sampled from mixtures.

We used pathogen populations rather than single isolates in our greenhouse assays of pathogenicity to better reflect field conditions. The population of $M$. graminicola in the Willamette Valley of Oregon is very large and highly diverse, with different pathogen genotypes commonly occurring even within the same lesion (24). Further, lesion density on our greenhouse-inoculated plants was similar to that which we commonly observe in the field. It has

TABLE 2. Disease severity caused by Mycosphaerella graminicola isolates from mixtures versus pure stands of wheat when inoculated on respective mixture component cultivars in the greenhouse

\begin{tabular}{lcccc}
\hline & & \multicolumn{2}{c}{ Disease severity } \\
\cline { 3 - 4 } Trial $^{\mathrm{a}}$ & Mixture $^{\mathrm{b}}$ & Mixture isolates $^{\mathrm{c}}$ & Pure-stand mean $^{\mathrm{d}}$ & $P>(t)^{\mathrm{e}}$ \\
\hline 1998 & $\mathrm{C} / \mathrm{S}$ & 10.8 & 13.3 & 0.4303 \\
& $\mathrm{C} / \mathrm{W}$ & 6.7 & 9.0 & 0.4795 \\
& $\mathrm{M} / \mathrm{S}$ & 9.5 & 15.9 & 0.0513 \\
& $\mathrm{M} / \mathrm{W}$ & 9.3 & 11.5 & 0.5002 \\
& Mean & 9.1 & 12.4 & 0.0850 \\
1999 & $\mathrm{C} / \mathrm{S}$ & 29.8 & 29.3 & 0.9624 \\
& $\mathrm{C} / \mathrm{W}$ & 44.5 & 39.8 & 0.6363 \\
& $\mathrm{M} / \mathrm{S}$ & 39.1 & 23.0 & 0.1049 \\
& $\mathrm{M} / \mathrm{W}$ & 31.6 & 33.6 & 0.8387 \\
& Mean & 36.2 & 31.4 & 0.4186 \\
& $\mathrm{C} / \mathrm{S}$ & 24.7 & 9.8 & 0.0430 \\
& $\mathrm{C} / \mathrm{W}$ & 27.6 & 19.2 & 0.8588 \\
& M/S & 30.2 & 11.8 & 0.0592 \\
& M/W & 13.9 & 21.2 & 0.1146 \\
& Mean & 24.1 & 14.8 & 0.2940 \\
\hline
\end{tabular}

a Year of isolate collection. Disease values reported for 1999 are means of two tests of those isolates.

b Isolates were obtained from pure stands and 1:1 mixtures of moderately resistant and susceptible cultivars. Moderately resistant: $\mathrm{C}=\mathrm{Cashup}, \mathrm{M}=$ Madsen. Susceptible: $\mathrm{S}=$ Stephens, W = W-301.

${ }^{c}$ Mean percent diseased leaf area on the two tester cultivars that comprised a mixture (e.g., the mean for the 'Cashup'/'Stephens' mixture population when tested separately on 'Cashup' and on 'Stephens'). Values are means of four replicates.

${ }^{\mathrm{d}}$ Mean disease severity caused by isolate populations from pure stands of cultivars comprising the mixture when tested on seedlings of their cultivar of origin (e.g., the mean severity when 'Cashup' populations were tested on 'Cashup' and 'Stephens' populations were tested on 'Stephens'). Values are means of four replicates.

e Significance based on linear contrasts of the difference in disease severities caused by mixture and pure-stand isolates. been demonstrated that mixtures of $M$. graminicola isolates can cause more or less disease than the mean of individual isolates in greenhouse inoculations (37), a potential complication for our results. For such interactions to explain the differences in pathogenicity that we observed among years in this study, however, would require substantially different pathogen populations among years, which seems unlikely. Founder effects are highly unlikely for this pathogen in the Willamette Valley of Oregon, where founding populations of at least 70 genetically distinct individuals have been estimated per square meter in the field (38). Further, there were no substantial changes in the number of cultivars or the proportion occupied by each cultivar of total Willamette Valley wheat area during the period of 1998 to 2000.

Populations sampled from the 'Madsen'/'Stephens' mixture in both 1999 and 2000 were significantly $(P=0.076$ and 0.059$)$ more pathogenic to cvs. Madsen and Stephens than were the purestand populations (Table 2). The M. graminicola population of Oregon's Willamette Valley is likely to be adapted to cvs. Madsen and Stephens, the dominant cultivars in commercial cultivation. From 1995 to 2000, the share of total soft white winter wheat area in the valley that was planted to each of those two cultivars ranged from $20 \%$ to over $60 \%$. Why the M. graminicola populations sampled in 1998 from the 'Madsen'/'Stephens' mixture were less pathogenic than those from the pure stands is unclear.

Relationship between mixture effects on epidemics and on pathogenicity. Effects of mixtures in suppressing epidemics were associated with selective effects on pathogenicity. In 1998, AUDPCs of mixtures were lower than the pure-stand means and populations sampled from mixtures were less pathogenic than those sampled from pure stands. In 1999, mixtures did not reduce disease severity and pathogenicity did not differ significantly for populations sampled from mixtures and pure stands. In 2000, there was on average significantly $(P=0.053)$ more disease in mixtures relative to pure stands in the field and two of the four populations sampled from mixtures were more pathogenic compared with those sampled from pure stands.

The question arises whether the differences in pathogenicity among years were cause or effect, i.e., did mixtures exercise different selective influences among the years, or did differences among the pathogen populations among years cause mixtures to vary in epidemiological impact? While we have no definitive answer, it seems improbable that the pathogen population differed greatly from year to year, as noted above.

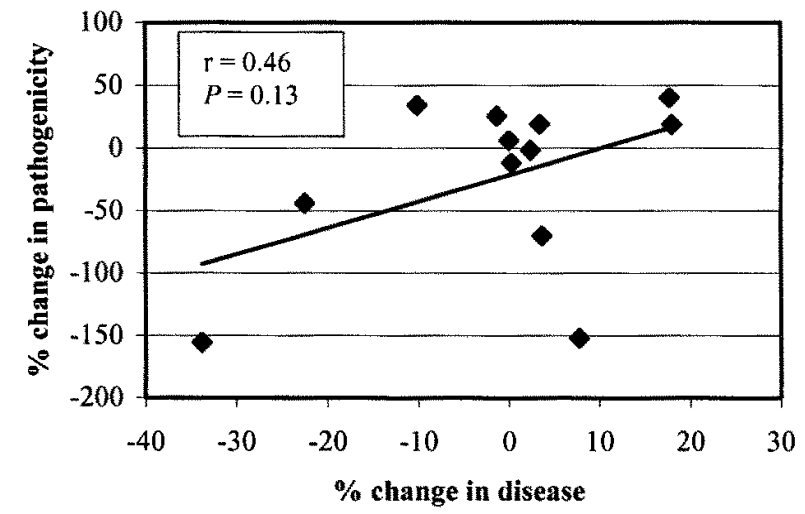

Fig. 4. Relationship between effects of winter wheat mixtures on Septoria tritici blotch severity in the field and their effects on pathogenicity of $\mathrm{Myco}$ sphaerella graminicola populations derived from them. Along the $x$ axis are plotted the percent differences between areas under the disease progress curve (AUDPCs) in mixture plots and mean AUDPCs of component pure stands. Along the $y$ axis are plotted the percent differences between mean disease severities caused by mixture populations on the two cultivars of origin and mean disease severity caused by populations from component pure stands when tested on their respective cultivars of origin in the greenhouse. Data are means of four replicates. 
A possible explanation for the different effects of mixtures on disease and pathogenicity that were observed in different years is based on the interaction of leaf emergence and rain-mediated spore dispersal. Our MR cultivars were later-maturing than the susceptible cultivars by between 2 and 7 days. Infection severity in a particular leaf layer is highly dependent on the precise timing of leaf emergence in relation to high-impact rain (30). Appropriately timed rain-splash could infect recently emerged leaves of an susceptible cultivar before the same leaves had fully emerged on an MR cultivar. After the latent period, MR leaves would be infected by same-layer susceptible leaves in mixture plots but not in pure-stand MR plots. Under this scenario, more pathogen generations would occur on MR cultivars in mixtures than in pure stands, allowing more opportunity for selection of increased pathogenicity. Thus, the different effects of mixtures in 1998 and 2000, years with similar average levels of ultimate disease severity, would be attributable to different timings of splashy rainfall with respect to emergence of successive leaf layers. Consistent with such an explanation is the fact that disease severity on the MR cultivars in our study was considerably lower as a percentage of severity on the two susceptible cultivars in 2000 than in the other 2 years.

In summary, host diversity effects on $M$. graminicola appear variable and environmentally influenced. Overall, this set of mixtures did not reduce disease severity or pathogenicity in the environments tested.

\section{ACKNOWLEDGMENTS}

We thank D. Coyle, M. Hoffer, and K. Webb for invaluable technical assistance, C. Pereira for helpful statistical advice, and K. B. Johnson and the anonymous reviewers for thoughtful suggestions that improved the manuscript.

\section{LITERATURE CITED}

1. Abbott, D. C., Burdon, J. J., Brown, A. H. D., Read, B. J., and Bittisnich, D. 2000. The incidence of barley scald in cultivar mixtures. Aust. J. Agric. Res. 51:355-360.

2. Ahmed, H. U., Mundt, C. C., and Coakley, S. M. 1995. Host-pathogen relationship of geographically diverse isolates of Septoria tritici and wheat cultivars. Plant Pathol. 44:838-847.

3. Ahmed, H. U., Mundt, C. C., Hoffer, M. E., and Coakley, S. M. 1996. Selective influence of wheat cultivars on pathogenicity of Mycosphaerella graminicola (anamorph Septoria tritici). Phytopathology 86:454-458.

4. Barrett, J. A. 1980. Pathogen evolution in multilines and variety mixtures. Z. Pflanzenkrankh. 87:383-396.

5. Bell, G. 1997. Selection: The Mechanism of Evolution. Chapman \& Hall, New York.

6. Browning, J. A., and Frey, K. J. 1969. Multiline cultivars as a means of disease control. Annu. Rev. Phytopathol. 7:355-381.

7. Campbell, C. L., and Madden, L. V. 1990. Introduction to Plant Disease Epidemiology. John Wiley \& Sons, New York.

8. Chin, K. M., and Wolfe, M. S. 1984. Selection of Erysiphe graminis in pure and mixed stands of barley. Plant Pathol. 33:535-546.

9. Cowger, C., Hoffer, M. E., and Mundt, C. C. 2000. Specific adaptation by Mycosphaerella graminicola to a resistant wheat cultivar. Plant Pathol. 49:445-451.

10. DiLeone, J. A., and Mundt, C. C. 1994. Effect of wheat cultivar mixtures on populations of Puccinia striiformis races. Plant Pathol. 43:917-930.

11. Eyal, Z. 1999. Breeding for resistance to Septoria and Stagonospora diseases of wheat. Pages 115-130 in: Septoria on Cereals: A Study of Pathosystems. J. A. Lucas, P. Bowyer, and A. M. Anderson, eds. CAB International, Wallingford, UK.

12. Finckh, M. R., Gacek, E. S., Goyeau, H., Lannou, C., Merz, U., Mundt, C. C., Munk, L., Nadziak, J., Newton, A. C., de Vallavieille-Pope, C., and Wolfe, M. S. 2000. Cereal variety and species mixtures in practice, with emphasis on disease resistance. Agronomie 20:813-837.
13. Garrett, K. A., and Mundt, C. C. 1999. Epidemiology in mixed host populations. Phytopathology 89:984-990.

14. Jeger, M. J., Griffiths, E., and Jones, D. G. 1981. Disease progress of non-specialised fungal pathogens in intraspecific mixed stands of cereal cultivars. I. Models. Ann. Appl. Biol. 98:187-198.

15. Jeger, M. J., Griffiths, E., and Jones, D. G. 1981. Disease progress of non-specialised fungal pathogens in intraspecific mixed stands of cereal cultivars. II. Field experiments. Ann. Appl. Biol. 98:199-210.

16. Jeger, M. J., Griffiths, E., and Jones, D. G. 1981. Effects of cereal cultivar mixtures on disease epidemics caused by splash-dispersed pathogens. Pages 81-88 in: Strategies For the Control of Cereal Disease. J. F. Jenkyn and R. T. Plumb, eds. Blackwell Scientific Publications, Oxford, UK.

17. Karow, R. S., ed. 1995. Winter Cereal Varieties for 1995. Oreg. State Univ. Ext. Serv. Spec. Rep. 775.

18. Karow, R. S., ed. 1996. Winter Cereal Varieties for 1996. Oreg. State Univ. Ext. Serv. Spec. Rep. 775.

19. Kiyosawa, S. 1989. Breakdown of blast resistance in relation to general strategies of resistance gene deployment to prolong effectiveness of disease resistance in plants. Pages 251-283 in: Plant Disease Epidemiology, Vol. 2. K. J. Leonard and W. E. Fry, eds. McGraw-Hill, New York.

20. Leonard, K. J. 1969. Selection in heterogeneous populations of Puccinia graminis f. sp. avenae. Phytopathology 59:1851-1857.

21. Leonard, K. J., and Czochor, R. J. 1980. Theory of genetic interactions among populations of plants and their parasites. Annu. Rev. Phytopathol. 18:237-258.

22. Manthey, R., and Fehrmann, H. 1993. Effect of cultivar mixtures in wheat on fungal diseases, yield and profitability. Crop Prot. 12:63-68.

23. Marshall, D. R. 1989. Modeling the effects of multiline varieties on the population genetics of plant pathogens. Pages 81-88 in: Plant Disease Epidemiology, Vol. 2. Genetics, Resistance and Management. K. J. Leonard and W. E. Fry, eds. McGraw-Hill, New York.

24. McDonald, B. A., and Martinez, J. P. 1990. DNA restriction fragment length polymorphisms among Mycosphaerella graminicola (anamorph Septoria tritici) isolates collected from a single wheat field. Phytopathology 80:1368-1373.

25. Mille, B., and Jouan, B. 1997. Influence of varietal associations on the development of leaf and glume blotch and brown leaf rust in winter bread wheat. Agronomie 17:247-251.

26. Mundt, C. C., Brophy, L. S., and Schmitt, M. E. 1995. Choosing crop cultivars and cultivar mixtures under low versus high disease pressure: A case study with wheat. Crop Prot. 14:509-515.

27. Mundt, C. C., and Browning, J. A. 1985. Development of crown rust epidemics in genetically diverse oat populations: Effect of genotype unit area. Phytopathology 75:607-610.

28. Mundt, C. C., and Leonard, K. J. 1986. Analysis of factors affecting disease increase and spread in mixtures of immune and susceptible plants in computer-simulated epidemics. Phytopathology 76:832-840.

29. Østergaard, H. 1983. Predicting development of epidemics on cultivar mixtures. Phytopathology 73:166-172.

30. Royle, D. J., Shaw, M. W., and Cook, R. J. 1986. Patterns of development of Septoria nodorum and S. tritici in some winter wheat crops in Western Europe, 1981-83. Plant Pathol. 35:466-476.

31. Shaner, G., and Finney, R. E. 1976. Weather and epidemics of Septoria leaf blotch of wheat. Phytopathology 66:781-785.

32. Shaw, M. W. 1990. Effects of temperature, leaf wetness and cultivar on the latent period of Mycosphaerella graminicola on winter wheat. Plant Pathol. 39:255-268.

33. Thomas, M. R., Cook, R. J., and King, J. E. 1989. Factors affecting development of Septoria tritici in winter wheat and its effect on yield. Plant Pathol. 38:246-257.

34. Tyldesley, J. B., and Thompson, N. 1980. Forecasting Septoria nodorum on winter wheat in England and Wales. Plant Pathol. 29:9-20.

35. Vanderplank, J. E. 1968. Disease Resistance in Plants. Academic Press, New York.

36. Wolfe, M. S. 1985. The current status and prospects of multiline cultivars and variety mixtures for disease resistance. Annu. Rev. Phytopathol. 23:251-273.

37. Zelikovitch, N., and Eyal, Z. 1991. Reduction in pycnidial coverage after inoculation of wheat with mixtures of isolates of Septoria tritici. Plant Dis. 75:907-910.

38. Zhan, J., Mundt, C. C., and McDonald, B. A. 2001. Using restriction fragment length polymorphisms to assess temporal variation and estimate the number of ascospores that initiate epidemics in field populations of Mycosphaerella graminicola. Phytopathology 91:1011-1017. 